\title{
A regulations' survey for the wireless telecommunications deployment in Colombia
}

\author{
Estudio de las regulaciones colombianas para instalar \\ infraestructuras de telecomunicaciones inalámbricas
}

\section{Estudo das regulamentações colombianas para instalar infraestruturas de telecomunicações sem fio}

Fecha de recepción: 08 de noviembre de 2015

Fecha de aprobación: 14 de diciembre de 2015
José Gustavo Morales-Guarín Herman Antonio Fernández-González"

Paola Astrid Ortega-Sánchez

\section{Abstract}

This paper describes the current wireless telecommunications infrastructure deployment regulations in Colombia. It also refers to the possible effects that this infrastructure could cause to the country`s health and environment. similarly, the results obtained show a comparison between the Argentina's current regulations, one of the most relevant researches carried out and the Colombian case. finally, some recommendations are proposed that can be considered in the project of regulations applicable in Colombia for the ensuring purpose that the non-ionizing radiation generated by wireless communications systems do not have effects on health and the environment.

Keywords: Regulation of telecommunications, Non-ionizing radiation, (NIR) Communications and health, Visual pollution telecommunications, Infrastructure deployment.

\section{Resumen}

Describe las actuales regulaciones colombianas para la instalación de infraestructuras de telecomunicaciones inalámbricas. También se refiere a los posibles efectos de esta infraestructura sobre la salud de la población y el medioambiente del país. Además, muestra los resultados de una comparación entre las actuales regulaciones de Argentina y el caso colombiano. Finalmente, se proponen algunas recomendaciones que pueden considerarse en

\footnotetext{
* M.Sc. (c) Gobernación de Boyacá (Tunja - Boyacá, Colombia).

** Ph.D. Universidad Pedagógica y Tecnológica de Colombia (Sogamoso - Boyacá, Colombia). herman.fernandez@uptc.edu.co.

*** M.Sc. Universidad Pedagógica y Tecnológica de Colombia (Duitama - Boyacá, Colombia).paola.ortega01@uptc.edu.co.
} 
el proyecto regulatorio aplicable a Colombia, con el propósito de asegurar que la radiación no ionizada generada por los sistemas inalámbricos de comunicaciones no afecte la salud y el medioambiente.

Palabras clave: Regulación de telecomunicaciones, Radiación no ionizante (RNI), Comunicaciones y salud, Polución visual, Instalación de infraestructura.

\section{Resumo}

Descreve as atuais regulamentações colombianas para a instalação de infraestruturas de telecomunicações sem fio. Também se refere aos possíveis efeitos desta infraestrutura sobre a saúde da população e o meio ambiente do país. Além disso, mostra os resultados de uma comparação entre as atuais regulamentações da Argentina e o caso colombiano. Finalmente, propõem-se algumas recomendações que podem considerar-se no projeto regulatório aplicável à Colômbia, com o propósito de assegurar que a radiação não ionizada gerada pelos sistemas sem fio de comunicações não afete a saúde e o meio ambiente.

Palavras chave: Regulamentação de telecomunicações, Radiação não ionizante (RNI), Comunicações e saúde, Poluição visual, Instalação de infraestrutura.

Cómo citar este artículo:

[1] J. G. Morales-Guarín, H. A. Fernández-González \& P. A. Ortega-Sánchez, “A regulations’ survey for the wireless telecommunications deployment in Colombia”, Fac. Ing., vol. 25 (41), pp. 21-30, ene.-abr. 2016. 


\section{INTRODUCTION}

The Colombian current legislation on Telecommunications, Decree 195 and Resolution 1645 (2005), compared to non-ionizing radiation (NIR) have been issued on the recommendation ITU K-52 regarding the measurement methodology and the maximum exposure levels. However multiple telecommunication based stations were declared inherently compliant, specifically in Article 2 of the resolution mentioned [1] which means, that periodic field-strength measurements must not be taken. Among the stations that were declared inherently compliant, are the mobile stations, which have had a major deployment without adequate control [2]. This has created opposition to such deployment from some communities, due to the effects caused uncertainty on the environment and the health of those living near the place where the infrastructure is installed.

After the date by which Colombia introduced the regulations in force, new recommendations have been proposed by the International Telecommunication Union (ITU) and new scientific articles have been published [3-10], confirming the need to proper control over the deployment of wireless telecommunications infrastructure. For this reason and by studying success cases regulations applied in other countries such as Argentina, Spain, Brazil, Italy and Salvador, the regulations update is needed in Colombia. From now on, in this article, the comparison will be only with Argentina.

Although Colombia currently has the code of good practice in the deployment of wireless telecommunications infrastructure [2] and a pilot plan NIR measurements in real time, and in the main cities of the country [11], it is necessary to conduct a study on researches that have been done, plus international recommendations and success cases in other countries, to host the best regulations in Colombia, in order to make them law of the Republic benefiting all Colombians.

This article in section I describes the possible NIR's effects on human health, considering some scientific studies which were presented by the mobile users and the recommendations of international organizations. section II presents the visual pollution caused by wireless telecommunications infrastructure and the way to counteract in both rural and urban areas. In section III a study of the current regulations in Colombia is done, against the deployment of communications infrastructure specifically RNI emissions and visual pollution. Later in section IV, a comparative analysis of the regulations in force in Colombia with regard to the regulations of Argentina, the $\mathrm{K} 83$ recommendation by ITU and some scientific studies done are shown, in order to help the guidelines that the new regulations in Colombia must have. Finally, in section V, the conclusions of this research are presented.

\section{Methodology}

It was initially planned to have a study based on some scientific papers, related to the effects of electromagnetic fields on living organisms [3-6], using databases such as Scopus, IEEE Xplore digital library, Science Direct, Electro Magnetic Field website (EMF) [12]; consultations were also undertaken with international bodies issuing recommendations in this regard: ITU, The International Commission on NonIonizing Radiation Protection (ICNIRP) and the World Health Organization (WHO). Thereafter, a study on Colombian current regulations was carried out, against the limitation and mitigation of adverse effects caused by the infrastructure of wireless telecommunications, i.e., the rules at different levels (constitution, law, decree, resolution).

With the procedure outlined, relevant documentation for this article's analysis was achieved based on four lines: national regulations, international recommendations, Argentina case study and scientific researches.

Having the documentation on these four lines, a timely comparison on different topics was made demonstrating the lag in national regulations, compared to Argentina and international recommendations. The need to update national standards relied on scientific research and international recommendations was also demonstrated.

\section{EFFECTS OF NIR ON HUMAN HEALTH}

In the latest years, since the creation of wireless telecommunications systems, a conflict arises as to whether these systems' electromagnetic radiation, with certain levels of field strength, has actually led potential harms to human health. In this regard high number of investigations have been developed and they also have headed the creation of an informatics 
portal known as EMF [12], where studies linking electromagnetic fields with possible effects on human health are stored. Up to April 2015, there were a total of 20,949 items, from which 206 are directly related to the fields strength's effects caused by the mobile telecommunications systems [12].

\section{A. Scientific articles}

Scientific papers stored in the EMF website, have pointed out different types of diseases among which are brain cancer, leukemia, cancer of the organs close to where mobile phones are carried, hypersensitivity to electromagnetic fields and genetic problems. Three types of disease are highlighted, brain cancer, hypersensitivity and genetic damage. On this basis the emphasis will be elaborated in the following sections.

About brain cancer, there are investigations, mostly case studies that evaluate the relationship between the use of cellular phone services and this disease The most recent of these studies on brain cancer was published in 2014 by S. Lagorio and M. Röösli in which they identify three different kinds of brain cancer: Glioma, meningioma, and acoustic neuroma, concluding that the relative risk from the use of mobile phone service for meningioma is minimal, while there is some risk for glioma and acoustic neuroma [13].

In England BENSON VS. conducted a populationbased study in 2005- 2012 to evaluate 791.710 cases of brain cancer, and its relationship with the use of mobile phone systems, concluding that there is no link between the use of mobile telephony systems and types of cancer: glioma and meningioma, while there is a strong connection with cases of acoustic neuroma, depending on the time of exposure, that is, the longer exposition to these systems, the acoustic neuroma risk increases [14].

Another disease related to the issue of NIR produced by mobile telephone systems, is the hypersensitivity that such fields may develop; in 2014 BALIATSAS C. published an article synthesizing the results of the case studies involving 5,789 patients in Netherlands and finding out that 5,073 were not sensitive, 514 were sensitive to general components from the environment and 202 were hypersensitive to electromagnetic fields, this figure reaches only $3.5 \%$ but even when levels are very low, there are a high sensitivity to such fields [3].
Genetic modifications are an effect from exposure to NIR fields, G. Gandhi conducted a study in which he made evident that the average power density of dwellings, that are within $300 \mathrm{~m}$ of the base stations is $11.49 \mathrm{~W} / \mathrm{m} 2$, while in dwellings that are further away, that density is $0.045 \mathrm{~W} / \mathrm{m} 2$ on average. Furthermore, Gandhi identified the genetic adverse effects, finding that the population exposed to higher levels of power density, showed damage in the DNA fragments' length [6].

\section{B. Mobile pperators studies}

Studies such as those conducted by the Global System Mobile Association (GSMA), system owners claiming that the radiation emitted by mobile stations do not generate any kind of impact on human health and the radiation level indicator is only $0.1 \%$, well below the legally established levels by the ICNIRP [17], GSMA also states that the radiation pattern emitted by mobile stations is horizontal, as illustrated in Fig. 1. In this way the inhabitants of the surrounding populations are not harmed, according this association [15].

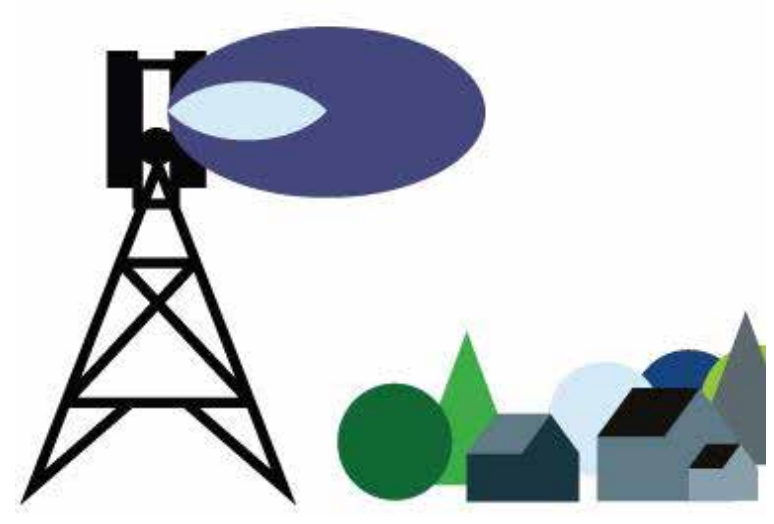

Fig. 1. Mobile telephony field emission [15].

\section{Recommendations issued by international organizations}

The principal global policy-making body regulating the health is the WHO, which has an internal agency specialized to research into the causes of human cancer, called The International Agency for Research on Cancer (IARC) and has a scale to determine the risk level of carcinogens, where exposure to the NIR produced by wireless telecommunications stations is classified as possibly carcinogenic [4]. Also, after the 
fact the Backgrounder 304, May 2006 was issued by the WHO as one of its paragraphs textually states:

Considering the very low exposure levels and research results collected to date, there is no convincing scientific evidence that the weak RF signals from base stations and wireless networks cause adverse health effects [16].

Furthermore the ICNIRP defined two tables with protection levels for NIR fields, one establishes the maximum population levels, i.e., to which the general population may be exposed and another table for occupational levels. In other words, the level to which staff are exposed when working with NIR fields. Thus, this employers association recognizes the existence of electric and magnetic field strength levels that might be a risk in humans. That is why users do not have to exceed them. The levels for radio frequency $(3 \mathrm{KHz}-$ $300 \mathrm{GHz}$ ) are presented in Table I. where the highest levels corresponding to the lowest frequency [17].

\section{TABLE I}

LEVELS FOR EXPOSURE DEFINED BY ICNIRP

\begin{tabular}{|l|c|c|}
\hline & Electric & Magnetic \\
& field & field \\
& strength & strength \\
& $\left(\mathrm{Vm}^{-1}\right)$ & $\left(\mathrm{Am}^{-1}\right)$ \\
\hline General & $61-87$ & $0,16-5$ \\
Public & & \\
\hline Occupational & $137-610$ & $0,36-24,4$ \\
\hline
\end{tabular}

Source: ICNIRP [17]

The ITU is the is the United Nations specialized agency responsible for issuing recommendations on telecommunications. It has different series by subject, in the specific case of the NIR, it is part of the K series, which is in charge of protection against radio fields interference. Recommendation K52 initially was published to guide on taking specific measures to determine radiation levels emitted by each of the radiation sources. In 2011, recommendation ITU-T $\mathrm{K} 83$ was issued, this recommendation provides long- term measurements and in real time, the measurements are presented on a map for a web site; Fig. 2 illustrates the system proposed by the recommendation K83.

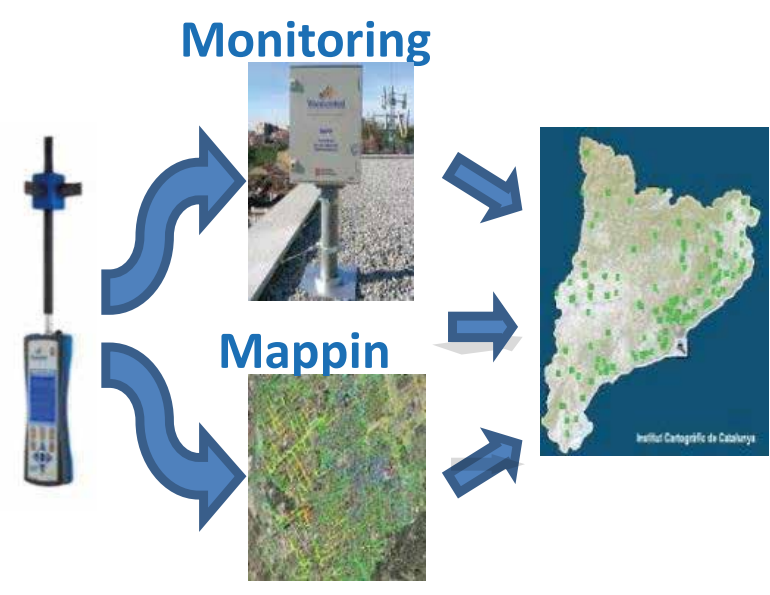

Fig. 2. Recommendation ITU-T K.83 methodology [18].

For the researchers who analyzed this article, it is not yet established with certainty whether the fields emitted by wireless telecommunications systems affect health; what is clear in Colombia, is that it has generated fear in society to those possible effects. MZ Netzer has called this fear as electro phobia [9], and this widespread phobia in society prevents proper deployment of communications infrastructure thereby, limiting the quality of service.

These fears have been demonstrated through different actions for protection presented by the community, claiming the fundamental right to health, and claiming that their health has been affected by the existing infrastructure around their homes. Two of these actions for protection have come to the Colombian Constitutional Court's review and have been resolved through sentences. One of these is the sentence T360 of 2010, where the need to apply the precautionary principle in regulating the NIR is presented [19] and the most recent sentence T 1077 in 2012 ordering the mobile operator, to dismantle its telecommunications infrastructure and reiterating the order to be taken, to regulate the matter using the precautionary principle [20]. 


\section{ENVIROMENTAL IMPACTS}

In addition to the possible effects on health by NIR causing community fears, the damage to the environment is also found and it is caused by the visual pollution as illustrated in Fig. 3. Given this situation, municipalities create barriers in their development plans, to the proper deployment of infrastructure to ensure quality standards required by users.

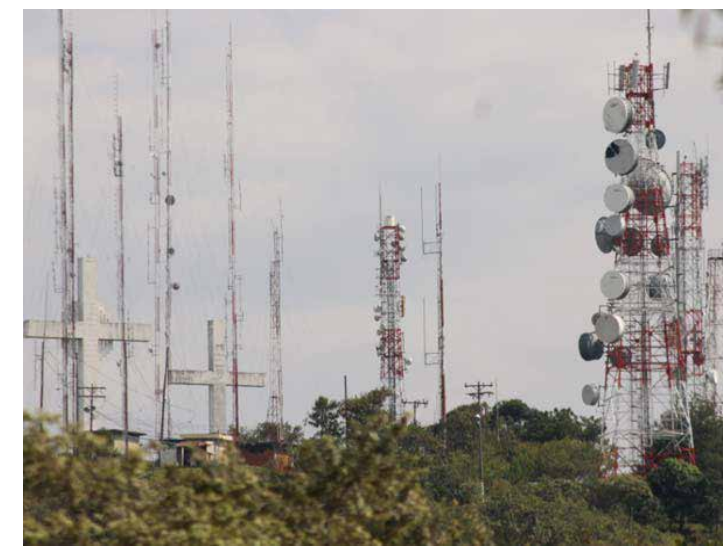

Fig. 3. Visual pollution caused by telecommunications infrastructure.

Uninstalling or relocation infrastructure is not necessary to counter the visual pollution; there are mechanisms of mimicry that can significantly reduce the environmental pollution, caused by the disorderly unwinding of this infrastructure [21]. Fig. 4 illustrates examples of infrastructure mimicry in both rural and urban areas.

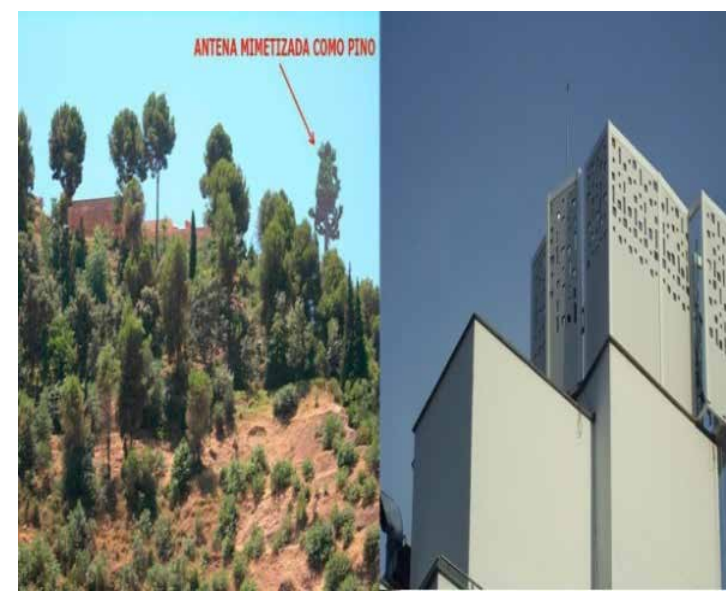

Fig. 4. Mimicry in rural and urban areas [22].
The materials for mimicry must follow special characteristics, such as the low degree of functional and aesthetic impairment and they must not interfere with stations radiation degrading the quality of service.

\section{Regulations in Colombia}

As Article 75 of the Political Constitution of Colombia states: "The electromagnetic spectrum is an inalienable and imprescriptible public asset subject to the management and control of the state", whereby an explicit obligation on the State to exercise control over the spectrum is made, the levels of radiation should be clearly included in this control and they must not go against the right to health, and the duty to ensure the comprehensive health care established by Article 49 of the Constitution.

In addition, Article 2 of the Constitution, creates a State obligation as important decision-maker for health care. Thus, if radiation emissions may affect citizens, they must take concrete action in these decisions. On the other hand the Constitution in Article 79 stipulates: "Everyone has the right to enjoy a healthy environment" and enjoying an environment without visual pollution right, must be within this concept. Along these lines, a constitutional framework on the subject under study in this article, is needed in Colombia [23].

In the legal framework, the deployment of telecommunications infrastructure in the Law $1341 / 2009$, known as ICT law, one of the guiding principles of the efficient law is Article 2, which sets out the use of scarce resources within the radio spectrum is located, and one of the conditions for its use is that competence, quality and efficiency spectrum must be guaranteed. It also states that to achieve these objectives, national and territorial entities are required to take the necessary measures, to facilitate and guarantee the development of the required infrastructure, ensuring that has not side effects on public property or the public interest. This law also creates the National Spectrum Agency (NSA) in Article 25, which is in charge of designing and formulating policies based on monitoring spectrum with international standards, specifically mentioning the ITU [24].

Regarding NIR fields protection, the Decree 195/ 2005 is based on laws that were repealed by Act $1341 /$ 
2011, law 72 / 1989 and Decree Law 1900 / 1990 [24]. Decree 195/2005 establishes the obligation to perform measurements, the frequency range of issuers that must perform the measurements. This range is $9 \mathrm{KHz}$ and $3 \mathrm{GHz}$, and the decree was based on the ITU K52 recommendation and guidance, given for occupational exposures and exposure of the general public. The limiting exposure is the same established by the INCRIP and presented in Table I. Article 16 establishes the minimum requirements to deploy infrastructure too. Additionally, the decree 195/2005 establishes the obligation to regulate by resolution a declaration of inherently compliant sources, the methodology of measurement and verification processes [1].

As result of regulatory requirements by resolution set on the decree $195 / 2005$, resolution $1645 / 2005$ by the Ministry of Communications (ICT ministry today) in which some sources are established as inherently compliant as following:

- Mobile Cell Phones

- Personal Communication Services PCS

- Trunking Access System

- Radio messaging System (Beeper)

- Conventional Radio Communication System (HF Voice \& Data)

- Conventional Radio Communications System (VHF Voice \&Data)

- Conventional Radio Communications System (UHF Voice \& Data)

- Space Segment

Establishing the infrastructure to provide such services is not required to perform the measurements [25].

The resolution states the measurement methodology, indicating that it should be done in high traffic levels or use time, measuring with an electric field probe at a considerable distance from the radiation source, and describing two perpendicular paths, installing the measuring probe at a height of 1.7 meters. If the source is located near crowded areas, taking measures at such center is recommended, and if there are points that present high field strength, taking 6-minute verification measures are suggested, and finally making a map normalizing the measurements to the levels specified in Decree 195. The mitigation procedure when set exposure levels are exceeded, remains on narrowband measurements of each of the radiation sources, by determining which one contributes to the highest level and decreasing the level, until it reaches the level of the second one and so on, to affect the least possible the lowest radiation source [25].

Within the environmental considerations and potential environmental risks from RF exposure produced by the deployment of telecommunications infrastructure, the general law of environment in Colombia is the Law 99 /1993. This law does not enclose express declaration about visual pollution, however, the Title VIII defines the environmental permit notion and establishes the kind of activities which require environmental permits [26]. Responding to this mandate, the decree 2820/2010 is issued, and its Article 7 defines the activities that require environmental permits, but the deployment of the infrastructure necessary for the provision of telecommunications services is not included, and therefore, there is no commitment on environmental matters in the legal order for telecommunications infrastructure deployment [27].

In 2012, in response to the sentences T360/2010 and T1077/2012 [19, 20], the Communications Regulation Commission (CRC) and the NSA issued a guidance code for good practices, which are recommendations for the communications infrastructure deployment such as the mimicry, clear and expeditious procedures for the issuance of permits and reporting mechanisms to the community, this code was distributed to local authorities who, in their sole discretion, may adopt it [2].

Although it is clear that there are municipalities that have adopted these recommendations, such as Bucaramanga through Decree 0003 /2014 or Bogotá with Decree 676/ 2011, to abide mimicry and to stablish which sites can be used to deploy infrastructure, in other municipalities as Monteria, its 2011-2015 development plan instructs operators to dismantle its infrastructure in urban areas [28]. The above fact is based on electro phobia [9] and the lack of community awareness of the RF fields exposure levels and respective risks. As a result of widespread fear, the telecommunications industry also expressed its difficulty to provide quality service, given the numerous barriers that are imposed for the proper deployment of infrastructure [29].

\section{Outcomes}

To identify the advantages of current legislation in Argentina, compared with Colombia, some of the most significant researches and recommendation ITU-T 
K83 regarding to Colombia case study, in Table. II, a comparison against the criteria to be reformed is done. These are the inherently compliant systems, the mimicry of infrastructure and the socialization of telecommunications effects to the community.

TABLE II

BenCHMARKING OF COLOMBIAN REGULATIONS ON THE WIRELESS TELECOMMUNICATIONS INFRASTRUCTURE DEPLOYMENT

\begin{tabular}{|c|c|c|c|c|}
\hline CRITERIA & $\begin{array}{l}\text { REGULATIONS IN } \\
\text { COLOMBIA (Decree } \\
\text { 195/2005, Resolution } \\
1495 / 2005 \text { ) }\end{array}$ & \begin{tabular}{|l} 
INTERNACIONAL \\
RECOMENDATIONS \\
(Recommendation ITU-T \\
K83)
\end{tabular} & \begin{tabular}{|l} 
ARGENTINA \\
CASE STUDY \\
(Law 123, \\
Resolution \\
244-SMAyDS) \\
\end{tabular} & $\begin{array}{l}\text { SCIENTIFIC } \\
\text { ARTICLES } \\
{[3-10]}\end{array}$ \\
\hline $\begin{array}{l}\text { Reporting of } \\
\text { inherently } \\
\text { compliant } \\
\text { systems. }\end{array}$ & $\begin{array}{l}\text { Inherently compliant } \\
\text { systems are declared. }\end{array}$ & $\begin{array}{l}\text { Inherently compliant systems } \\
\text { are not declared. }\end{array}$ & \begin{tabular}{|l|} 
Inherently \\
compliant \\
systems are not \\
declared [30].
\end{tabular} & $\begin{array}{l}\text { Inherently } \\
\text { compliant } \\
\text { systems should } \\
\text { not be declared } \\
{[3-6] .}\end{array}$ \\
\hline $\begin{array}{l}\text { Mimicry of the } \\
\text { infrastructure }\end{array}$ & $\begin{array}{l}\text { Mimicry is not } \\
\text { mandatory }\end{array}$ & $\begin{array}{l}\text { There are no recommendations } \\
\text { on mimicry. }\end{array}$ & $\begin{array}{l}\text { Mimicry and } \\
\text { environmental } \\
\text { permits are } \\
\text { required. }\end{array}$ & $\begin{array}{l}\text { Mimicry is } \\
\text { necessary } \\
\text { to offset the } \\
\text { environmental } \\
\text { impacts }[7,8] .\end{array}$ \\
\hline $\begin{array}{l}\text { Socialization to } \\
\text { the community. }\end{array}$ & $\begin{array}{l}\text { Socialization of } \\
\text { Infrastructure side } \\
\text { effects is not required to } \\
\text { communities. }\end{array}$ & $\begin{array}{l}\text { There is socialization of } \\
\text { Infrastructure side effects to } \\
\text { communities. }\end{array}$ & $\begin{array}{l}\text { Measurements } \\
\text { are recorded } \\
\text { and there is } \\
\text { community } \\
\text { consultation. }\end{array}$ & $\begin{array}{l}\text { Regulations } \\
\text { must take the } \\
\text { preventive } \\
\text { principle } \\
\text { and there is } \\
\text { socialization to } \\
\text { the community } \\
{[9,10] .}\end{array}$ \\
\hline
\end{tabular}

As evidenced in Table II, of the studied rules, only Colombia has the declaration of inherently compliant sources, demonstrating that according to latest researches and recommendations, that declaration should not be enacted and instead must make realtime measurements that reveal actual radiation levels in different parts of the country.

Even if there is no specific recommendations for telecommunications mimicry infrastructure, the mobile companies report that one of the difficulties in the infrastructure deployment, is that some municipalities do not allowed them to install base stations in urban areas, taking into account the land management plans (Plan de Ordenamiento Territorial, POT) and the visual pollution produced [2]. Considering the investigation conducted by Morais, JF [9], and regulation in Argentina, this issue can be solved establishing mimicry infrastructure as a requirement, thus local authorities may agree by not having this visual pollution.

Finally, concerning to the socialization of the exposure levels, although interest in the NSA through the monitoring system, a continuous measurement should be taken and published as presented in Fig. 5. This system has only been installed in 15 cities, what is considered insufficient, even though there is not full coverage of the territory nor in the 1,123 municipalities, at least the capitals and intermediate cities should have such a system. 


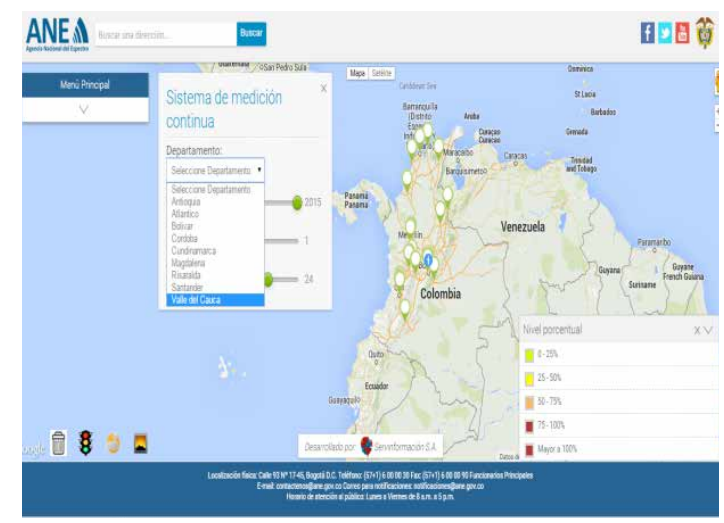

Fig. 5. Monitoring system in Colombia NSA [11].

The need to create a regulatory development that includes the following criteria is evident:

- Creation of requirements to continuously measure the NIR levels, at least in the capitals and intermediate cities.

- Establishing mimicry requirements for telecom towers reducing the visual pollution that is generated by this infrastructure.

- Based on studies and measurements, socializing to the community the possible side effects on health and the environment produced by wireless communications on human health and the mechanisms for its mitigation.

\section{Conclusions}

At present, there is no certainty about the human health side effects generated by NIR in telecommunication base stations.

Uncertainty and ignorance of the community over radiation levels exposure and visual pollution, cause opposition to the wireless telecommunications infrastructure deployment. Thus updating legislation to ensure the health protection and the environment is necessary, to allow the orderly deployment of infrastructure.

\section{REFERENCES}

[1] Colombia. Ministerio de Comunicaciones, Ministerio de Protección Social. Decreto 195 de 2005 "por el cual se adoptan límites de exposición de las personas a campos electromagnéticos, se adecúan procedimientos para la instalación de estaciones radioeléctricas y se dictan otras disposiciones”. Enero 31, 2005.

[2] J. P. Hernández, D. P. Morales. Código de Buenas Prácticas para el despliegue de infraestructura de redes de comunicaciones. Comisión de Regulación de Comunicaciones, Agencia Nacional del Espectro. 2012.

[3] C. Baliatsas, I. Van Kamp, M. Hooiveld, J. Yzermans, E. Lebret. "Comparing non-specific physical symptoms in environmentally sensitive patients: prevalence, duration, functional status and illness behavior". J. Psychosom Res, 76(5): 405-413. 2014. DOI: http://dx.doi. org/10.1016/j.jpsychores.2014.02.008.

[4] International Agency for Research On Cancer. IARC. Classifies Radiofrequency Electromagnetic Fields as Possibly Carcinogenic to Humans. 2011. Recuperado de http://www.iarc.fr/en/media-centre/pr/2011/ pdfs/pr208_E.pdf.

[5] D. Krewski, C. V. Byus, B. W. Glickman, W. G. Lotz, R. Mandeville, M. L. Mcbride, F. S. Prato, and D. F. Weaver. "Potential Health Risks of Radiofrequency Fields from Wireless Telecommunication Devices". Journal of Toxicology and Environmental Health - Part B: Critical Reviews 4, no. 1: 1-143. 2001. DOI: http://dx.doi.org/10.1080/109374001459458.

[6] G. Gandhi, G. Kaur, U. Nisar. "A cross-sectional case control study on genetic damage, in individuals residing in the vicinity of a mobile phone base station". Electromagnetic Biology and Medicine. 2014.

[7] O J. Tibasosa Bernal. Estudio de impacto ambiental de la contaminación visual causada por las estaciones de telefonía celular en Bogotá D.C. Tesis de grado. Universidad Militar Nueva Granada, Bogotá, D.C. Colombia. 2013.

[8] J. F. Morais, and G. L. Siqueira. "Wireless Technologies Environmental Impacts". In SBMO/IEEE MTT-S International Microwave and Optoelectronics Conference Proceedings, 523-527. 2009. DOI: http://dx.doi.org/10.1109/ imoc.2009.5427529.

[9] M.Z. Netzer. "Electrophobia and Misperception of Non-Ionizing Radiation Hazards. Electromagnetic Compatibility", 2003. EMC '03. IEEE International Symposium on 
Electromagnetic Compatibility (EMC), 2: 724727, 2003.

[10] M. Dolan, and J. Rowley. "The Precautionary Principle in the Context of Mobile Phone and Base Station Radiofrequency Exposures". Environmental Health Perspectives, 117 (9): 1329-1332, 2009. DOI: http://dx.doi. org/10.1289/ehp.0900727.

[11] Agencia Nacional del Espectro. Sistema de Medición Continua. Recuperado de http:// servidorweb2.sitimapa.com/ane/\#, 2014.

[12] University Hospital Rwth Aachen. EMF-portal. 2012. Recuperado de http://www.emf-portal. $\mathrm{de} / ? 1=\mathrm{e}$

[13] S. Lagorio, M. Röösli M. "Mobile phone use and risk of intracranial tumors: A consistency analysis". Bioelectromagnetics, 35 (2): 7990, 2014. DOI: http://dx.doi.org/10.1002/ bem. 21829 .

[14] V. S. Benson, K. Pirie, J. Schüz, G. K. Reeves, V. Beral, J. Green. "Mobile phone use and risk of brain neoplasms and other cancers: prospective study". Revista J Epidemiol, 42(3): 792-802, 2013. DOI: http://dx.doi.org/10.1093/ ije/dyt072.

[15] J. Rowley. Redes Móviles: Niveles de Exposición y Política de despliegue. GSMA, 2007.

[16] Organización Mundial de la Salud. Nota Descriptiva 304. 2006. Recuperado de http:// www.who.int/peh-emf/publications/facts/ fs304/es/

[17] ICNIRP. Aproximación general para la protección contra la radiación no-ionizante. 2007. Recuperado de http://www.icnirp.de/ documents/philosophyesp.pdf.

[18] H. Carril. Emisiones Electromagnéticas No Ionizantes y los despliegues de Redes Inalámbricas -Una Problemática Latinoamericana-. UIT, 2013.

[19] Corte Constitucional de Colombia. Sentencia T 360 de 2010 "Por la cual se resuelve acción de Tutela y se exhorta al ministerio TIC y a la Comisión de Regulación de Comunicaciones". 2010.

[20] Corte Constitucional de Colombia. Sentencia T 1077 de 2012 "Por la cual se ordena a Telefónica Telecom S.A. E.S.P. desmontar la estación base localizada en el inmueble ubicado en la calle $5^{\text {a }}$ con carrera $6^{\mathrm{a}}$ - Esquina, en Fresno, Tolima". 2012.
[21] ARBO S.A.S. Mimetizaciones. Recuperado de http://www.arbo-sas.com/main/ mimetizaciones.html. 2015.

[22] M. de los A. Sáenz. "Evaluación de la disponibilidad de la señal en El Albarracín". Revista Electrónica del Patrimonio Histórico. 2011. Recuperado de http://www. revistadepatrimonio.es/revistas/numero9/ intervencion/estudios/articulo5.php\#popup12.

[23] Colombia. Constitución Política de 1991. Bogotá: Legis. 2014.

[24] Colombia. Congreso de la República. Ley 1341 de 2009, por la cual se definen principios y conceptos sobre la sociedad de la información y la organización de las tecnologías de la información y las comunicaciones -TIC-, se crea la Agencia Nacional de Espectro y se dictan otras disposiciones. Bogotá, julio 30. 2014.

[25] Colombia. Ministerio de Comunicaciones. Resolución 1495 de 2005, "Por la cual se reglamenta el Decreto 195 de 2005". Julio 29 de 2005.

[26] Colombia. Congreso de la República. Ley 99 de 1993, "Por la cual se crea el Ministerio del Medio Ambiente, se reordena el Sector Público encargado de la gestión y conservación del medio ambiente y los recursos naturales renovables, se organiza el Sistema Nacional Ambiental, SINA, y se dictan otras disposiciones". Bogotá, diciembre 22 de 1993.

[27] Colombia. Ministerio de Ambiente y Desarrollo Territorial. Decreto 2820 de 2010, "Por el cual se reglamenta el Título VIII de la Ley 99 de 1993 sobre licencias ambientales". Bogotá. Agosto 5 de 2010.

[28] Concejo Municipal de Montería. Acuerdo 016 del 17 de noviembre de 2011 "Por el cual se expide el Plan de Desarrollo 2011-2015”. 2011.

[29] Revista Dinero. Operadores culpan a municipios por mala señal. 2013. Recuperado de http://www.dinero.com/empresas/articulo/ operadores-culpan-municipios-malasenal/175402.

[30] V. D. Frizzera. Radiaciones No Ionizantes Comisión Nacional de Comunicaciones de Argentina-. Recuperado de http://www.cnc. gob.ar/multimedia/noticias/archivos/201408/ archivo_20140821033028_6863.pdf. 2007. 